\title{
O DIREITO DE OBTER RESPOSTAS CONSTITUCIONALMENTE ADEQUADAS EM TEMPOS DE CRISE DO DIREITO: A NECESSÁRIA CONCRETIZAÇÃO DOS DIREITOS HUMANOS
}

Pós-doutorado em Direito pela Universidade de Lisboa (Portugal). Professor Titular do Programa de Pós-Graduação em Direito da UNISINOS (Mestrado e Doutorado). Professor visitante/colaborador da UNESA, Università degli Studi Roma Tre e Faculdade de Direito da Universidade de Coimbra. Procurador de Justiça (RS)

lenios@globo.com

Artigo submetido em português 


\section{A AUSÊNCIA DE FUNÇÃO SOCIAL DO E NO DIREITO COMO RESULTADO DE UMA CRISE PARADIGMÁTICA}

O século vinte proporcionou diversas rupturas paradigmáticas. Mais do que rupturas, podemos chamá-las de "revoluções copernicanas". Assim foi com Freud, que descobre o inconsciente e constrói as condições para o desenvolvimento da psicanálise. No campo do direito, ocorre uma viragem no direito constitucional, a partir das diversas constituições com nítido viés compromissório e dirigente, proporcionando um elevado grau de autonomia ao direito. Essa revolução copernicana atravessou o direito público em todos os seus ramos, fazendo com que as relações privadas perdessem a "plenipotenciariedade" que haviam adquirido no modelo formal-burguês de direito e de Estado.

Outra grande revolução ocorre com a invasão da filosofia pela linguagem, proporcionando um novo modo de compreender o mundo. Dois milênios de pensamento metafísico são superados em algumas décadas. Dizendo de outro modo: se, no paradigma da metafísica clássica, os sentidos "estavam" nas coisas e, na metafísica moderna, na mente (consciência de si do pensamento pensante), agora, nessa verdadeira guinada pós-metafísica, os sentidos passam a se dar na e pela linguagem.

As conseqüências dessa revolucionária viragem lingüístico-ontológica são incomensuráveis para a interpretação do direito. De terceira coisa que se interpõe entre um sujeito e um objeto, a linguagem passa à condição de possibilidade. Para além dos objetivismos e subjetivismos, a hermenêutica filosófica abre um novo espaço para a compreensão do direito e tudo o que representa a revolução copernicana proporcionada pelo novo constitucionalismo. Em outras palavras, essa segunda revolução é condição de possibilidade para o acontecer (Ereignen) da primeira. Passamos, pois, do fundamentar (metafísico) para o compreender (fenomenológico).

Na medida em que o direito é um fenômeno complexo - embora a cultura estandartizada que domina a doutrina e a jurisprudência brasileiras insista em simplicá-lo por intermédio de raciocínios pequeno-gnosiológicos (Warat) - as conquistas advindas dessas revoluções copernicanas deveriam produzir profundas modificações no campo jurídico. Ou seja, o direito não pode(ria) ficar imune/ blindado a essas transformações paradigmáticas. Entretanto, um exame do estado d’arte da doutrina predominante e do conjunto das decisões judiciais não proporciona uma visão otimista acerca dessa problemática.

Como venho insistindo em diversos trabalhos (Hermenêutica Jurídica em crise e Verdade e Consenso ${ }^{l}$ ), é preciso compreender que o direito, na medida em que não está imune às transformações ocorridas no campo filosófico, é um fenômeno inserido em uma intersubjetividade racional (chamada por Herbert Schnädelbach de "razão hermenêutica") e que deve ser sempre primeiramente produzida e garantida em processos de compreensão.

Por isso, "compreender sentido" não é apenas uma consequiência, mas o fundamento da própria razão. Visto assim, o problema hermenêutico não é apenas universal, mas, ao mesmo tempo, fundamental, isto é, sua solução já reside no âmbito da constituição de entendimento e razão e, desse modo, no campo avançado do problema do conhecimento, que Kant acreditava poder abordar com os meios dos conceitos do entendimento e da razão garantidos. Se, como tal, não existe razão sem compreensão de sentido, então o problema do sentido se situa sistematicamente antes do problema do conhecimento, pois devem ser pressupostos já como resolvidos, em todas as produções de conhecimento, os problemas da compreensão hermenêutica (Schnädelbach). Já no campo do conhecimento do direito, a questão é saber, de efetivo, de que modo um processo lógicoargumentativo pode "acontecer" sem a pré-compreensão. A pergunta é inevitável: afinal, é possível interpretar e, só depois, compreender? Por que isolar o conhecimento jurídico do fenômeno da 
compreensão?

A crise que atravessa a hermenêutica jurídica - e que tem reflexos incomensuráveis na aplicação/ concretização dos direitos humanos e fundamentais (que em ultima ratio são sociais) - possui uma relação direta com a discussão acerca da crise do conhecimento e do problema da fundamentação, própria do início do século XX. Veja-se que as várias tentativas de estabelecer regras ou cânones para o processo interpretativo a partir do predomínio da objetividade ou da subjetividade ou, até mesmo, de conjugar a subjetividade do intérprete com a objetividade do texto, não resistiram às teses da viragem lingüístico-ontológica (Heidegger-Gadamer). Esse giro lingüístico-ontológico, compreendido a partir do caráter ontológico prévio do conceito de sujeito e da desobjetificação provocada pelo circulo hermenêutico e pela diferença ontológica, supera o esquema sujeito-objeto. Para tanto, é de absolutamente relevante compreender que a viragem hermenêutico-ontológica, provocada por Sein und Zeit (1927) de Martin Heidegger, e a publicação, anos depois, de Wahrheit und Methode (1960), por Hans-Georg Gadamer, foram fundamentais para um novo olhar sobre a hermenêutica jurídica. Assim, a partir dessa ontologische Wendung, inicia-se o processo de superação dos paradigmas metafísicos objetivista aristotélico-tomista e subjetivista (filosofia da consciência), os quais, de um modo ou de outro, até hoje têm sustentado as teses exegético-dedutivistas-subsuntivas dominantes naquilo que vem sendo denominado de hermenêutica jurídica.

Essas sofisticadas questões estão ainda longe de serem recepcionadas pela comunidade jurídica. Recentemente saídos de um regime autoritário e mesmo estando sob a égide uma Constituição democrática e transformadora, continuamos a) com um Código Penal produto de uma sociedade que há pouco ingressara no liberalismo, voltado a uma (nova) clientela fruto da mudança da economia ocorrida a partir da revolução liberal de 1930; b) um Código Comercial que é do século XIX (agora "alterado", em parte, pelo Código Civil); c) com um Código de Processo Civil que, a par de estar calcado no protagonismo do juiz, que julga solipsisticamente, estabelece mecanismos que protegem explicitamente os direitos reais em detrimento dos direitos pessoais; d) por último, com um Código Civil de 1916 proveniente de uma sociedade pré-liberal e urbana, que somente foi alterado no ano de 2003, cujas modificações, entretanto, sofrem sérias restrições dos setores civilísticos mais críticos, principalmente por que o novo Código aposta demasiadamente na discricionariedade judicial (para tanto, veja-se as cláusulas gerais). A crise se instala, pois, a partir da confrontação entre uma Constituição compromissória e transformadora com um conjunto de leis incompatíveis com o escopo constitucional.

Tudo isso passa a ter influência e importância na análise do direito em nosso país. Como os juristas pensam o mundo e o direito? Como se inserem e como têm acesso ao mundo? O sentido comum teórico sufoca as possibilidades interpretativas dos juristas do mesmo modo que já sufocava no século passado. Quando submetido à pressão do novo, o jurista, refém do positivismo (em seus vários matizes), (re)age institucionalizando a crítica. Para tanto, abre possibilidades de dissidências apenas possíveis (delimitadas previamente). Trata-se, assim, de um jogo de cartas marcadas. Ou seja, no interior do sentido comum teórico, permite-se, difusamente, (apenas) o debate periférico, mediante a elaboração de respostas que não ultrapassem o teto hermenêutico prefixado (horizonte do sentido).

Inserido em um habitus dogmaticus, o jurista não se dá conta das contradições do sistema jurídico. Estas não "aparecem" aos seus olhos, uma vez que há um processo de justificação/fundamentação da "coerência" do seu próprio discurso. Por isso, esse processo de justificação não prescinde, para sua elucidação, do entendimento acerca do funcionamento da ideologia. Sim, porque essa discussão não morreu. Em outras palavras, ainda é necessário estudar o (velho) conceito de ideologia, que parece ter sido esquecido nas salas de aula das tantas faculdades de direito existentes pelo país 
afora. Talvez porque, como ensina Slavoj Zizek, a eficácia de uma ideologia é apreendida pelos mecanismos da identificação imaginária e da identificação simbólica. E, à primeira vista, poder-seia dizer que o que é pertinente numa análise da ideologia é somente a maneira pela qual ela funciona como discurso, em suma, pela maneira como os mecanismos discursivos constituem o campo da significação ideológica. No entanto, o derradeiro suporte do efeito ideológico (ou seja, a maneira como uma rede ideológica nos "prende") é o núcleo fora de sentido, pré-ideológico do gozo. Na ideologia "nem tudo é ideologia (isto é, sentido ideológico)", mas é precisamente esse excesso que constitui o derradeiro esteio da ideologia".

No plano da dogmática jurídica, os fenômenos sociais que chegam ao Judiciário passam a ser analisados como meras abstrações jurídicas, e as pessoas, protagonistas do processo, são transformadas em autor e réu, reclamante e reclamado, e, não raras vezes, em "suplicante" e "suplicado", expressões estas que, convenhamos, deveriam envergonhar (sobremodo) a todos nós. Mutatis mutandis, isso significa dizer que os conflitos sociais não entram nos fóruns e nos tribunais graças às barreiras criadas pelo discurso (censor) produzido pela dogmática jurídica dominante. Pode-se afirmar, desse modo, que ocorre uma espécie de "coisificação" (objetificação) das relações jurídicas.

Em face de tudo isso, outra pergunta se torna inevitável: que tipo de visão têm os operadores jurídicos, mergulhados nessa "inautenticidade" (no sentido hermenêutico da palavra), acerca da aplicação do direito? É evidente que a (con)formação do sentido comum teórico, enfim, do habitus dogmaticus, tem uma relação direta com o processo de aprendizagem nas escolas de direito e nas práticas dos tribunais. Com efeito, o imaginário jurídico continua preso às velhas práticas. Por mais que a pesquisa jurídica tenha evoluído a partir do crescimento do número de programas de pósgraduação, estes influxos reflexivos ainda estão distantes das salas de aula dos cursos de graduação, não se podendo olvidar, nesse contexto, que o crescimento da pós-graduação é infinitamente inferior à explosão do número de faculdades instaladas nos últimos anos.

A cultura calcada em manuais, muitos de duvidosa cientificidade, ainda é predominante na maioria das faculdades de direito. Aliás, pela "simploriedade" (sic) e pelo nível de estandardização de alguns livros jurídicos, deveria colocar-se uma tarja como aquelas que encontramos nos maços de cigarro: "o uso constante deste material fará mal a sua saúde mental”...!

Forma-se, assim, um imaginário que "simplifica" o direito ao ponto de já estar à venda uma nova forma de "doutrina": a dos "direitos descomplicados", em "quadros sinópticos" e até mesmo em folhas plastificadas, tudo à venda nos aeroportos, supermercados e rodoviárias de terrae brasilis. Essa “cultura fragmentária-pós-moderna" baseia-se em standards e lugares comuns, que são repetidos nas salas de aula e, posteriormente, nos cursos de preparação para concursos (hoje já existem cursinhos de preparação para ingresso nos cursinhos de preparação), bem como nos fóruns e tribunais.

Essa cultura alicerça-se em casuísmos didáticos, em que o positivismo - na verdade, a sua vulgata - ainda é a regra, uma vez que calcado, de um lado, em um objetivismo que não diferencia texto e norma e, de outro, em um subjetivismo que ignora os limites semânticos do texto jurídico. Portanto, desconfie-se tanto do professor que diz que a lei contém um sentido em si mesmo, como daquele que, pensando ser crítico, diz para os alunos: "a lei não importa muito, pois ela é apenas a ponta do iceberg..." - ambos são positivistas; desconfie-se igualmente daqueles que dizem que a interpretação é um ato de vontade ou que a interpretação é um ato "solitário", intuitivo e absolutamente subjetivo ou que "sentença vem de sentire"... também ali estão presentes outras formas de positivismo.

Mesmo que estejamos sob a égide de uma Constituição transformadora, é possível perceber, sem 
maior esforço, que a dogmática jurídica dominante (e reproduzida em boa parte dos manuais) continua a considerar o direito como sendo uma mera racionalidade instrumental. Em termos metodológicos, predomina o dedutivismo (sic), a partir da reprodução (in)consciente da metafísica relação sujeitoobjeto (registre-se: tanto a metafísica clássica como a metafísica moderna). Nesse contexto, o próprio ensino jurídico é encarado como uma terceira coisa, no interior da qual o professor é um outsider do sistema.

E o que é deve ser dito: lamentavelmente, a doutrina que sustenta o saber jurídico contenta-se com um conjunto de comentários resumidos de ementários de jurisprudência, desacompanhados dos respectivos contextos. Para ser mais claro: cada vez mais, a doutrina doutrina menos. Em outras palavras, a doutrina não doutrina mais, sendo, sim, "doutrinada/domesticada" pelos tribunais (lembremos, aqui, do famoso voto do Ministro Humberto Gomes de Barros, do Superior Tribunal de Justiça, no AgRg em EREsp n. ${ }^{\circ}$ 279.889-AL: "Não me importa o que pensam os doutrinadores" (...) Ninguém nos dá lições"). E o ensino acaba calcado em metodologias ad-hoc e sem consistência teórica, fenômeno que se dá com a construção de "categorias" "aptas para a produção de dedutivos", como se a realidade pudesse ser aprisionada pelo "paraíso dos conceitos do pragmatismo positivista dominante".

Não é desarrazoado afirmar, destarte, que a hermenêutica praticada nas salas de aula e nas sentenças e acórdãos continua absolutamente refratária ao giro linguiístico-ontológico; em regra, continua-se a estudar os métodos tradicionais de interpretação (gramatical, teleológico, etc.), como se o processo de interpretação pudesse ser feito em partes ou em fatias. Parece que a grande inovação dos últimos anos foi a descoberta da "ponderação", transformada em álibi teórico para decisionismos. Com o seu emprego e esgrimindo a teoria da argumentação, é possível decidir de qualquer modo, principalmente se for com base do princípio da proporcionalidade. Essa questão assume foros de dramaticidade se levarmos em conta o pan-principiologismo que domina a doutrina e a jurisprudência. Trata-se de uma espécie de "bolha especulativo-principiológica", pela qual o jurista/intérprete, na falta de uma lei adequada ou até mesmo da norma constitucional, lança mão de um catálogo interminável de princípios. Se princípios são normas - questão sobre a qual parece haver consenso (há pelos menos duzentas teses de doutorado no Brasil tratando disso) - o que fazer com "princípios" como da "precaução", "da rotatividade", "da afetividade", "da solidariedade", "da confiança no juiz de causa", "do fato consumado", "da humanidade”, "da cooperação", para falar de uma pequena parte desses standards retórico-performáticos?

A crise também é visível na Teoria do Estado, condição de possibilidade para o estudo do Direito Constitucional (para ficar nesta disciplina fundamental, que, aliás, não ocupa, na maioria dos cursos jurídicos, mais do que dois semestres), na medida em que não vem acompanhada da necessária interdisciplinariedade. Muito difícil encontrar discussões nos cursos de graduação tratando do surgimento do Estado Moderno a partir da ruptura com a forma estatal medieval, com a imbricação indispensável com o surgimento do novo príncípio epocal da modernidade, responsável pelo aparecimento da subjetividade, inexiste na metafísica clássica. De que modo os juristas poderão compreender o positivismo se não se lhes ensina o papel do sujeito no esquema sujeito-objeto? De que modo o jurista poderá compreender a principal característica do positivismo - a discricionariedade - se não se lhes ensina o representa e o que representou o sujeito solipsista (Selbstsüchtiger)? Isso para dizer o menos.

Em síntese: é preciso compreender que das condições da concretização da Constituição é, antes de tudo, uma crise do direito, que na realidade é uma crise de paradigmas, assentada em uma dupla face: uma crise de modelo e uma crise de caráter epistemológico. De um lado, os "operadores" (sic) do direito continuam reféns de uma crise emanada da tradição liberal-individualista-normativista 
(e iluminista, em alguns aspectos); e, de outro, da crise dos paradigmas epistemológico da filosofia da consciência - metafísica moderna - e aristotélico-tomista, da metafísica clássica. $\mathrm{O}$ resultado dessa(s) crise(s) é um direito alienado da sociedade, questão que assume foros de dramaticidade se compararmos o texto da Constituição com as promessas da modernidade incumpridas.

Disso tudo, é possível extrair a seguinte assertiva: ou se acaba com a estandardização do direito ou ela acaba com o que resta da ciência jurídica. Afinal, passados tantos anos e em pleno paradigma do Estado Democrático de Direito, do giro lingüístico e do novo constitucionalismo,

a) ainda não se construiu um modelo de ensino que "supere" a leitura de leis e códigos comentados (na maioria das vezes, reproduzindo conceitos lexicográficos e sem nenhuma sofisticação teórica);

b) a doutrina está dominada por produções que buscam, nos repositórios jurisprudenciais, ementas que descrevem, brevissimamente, o conceito do texto enquanto "enunciado lingüístico";

c) uma simples decisão de tribunal vira referência - plenipotenciária - para a atribuição de sentido do texto, perdendo-se a especificidade da situação concreta que a gerou;

d) em muitos casos, interpretam-se as leis e os códigos com base em julgados anteriores à Constituição, o que faz com que determinados dispositivos, mesmo que sob um novo fundamento de validade, sejam interpretados de acordo com a ordem jurídica anterior;

e) a doutrina especializada em comentários de legislação não tem feito uma filtragem hermenêuticoconstitucional dos Códigos e leis, com o que os casos nítidos de aplicação direta da Constituição acabam soçobrando em face da legislação produzida há mais de cinqüenta anos; exemplo candente, nesse sentido, foi o caso da presença (obrigatória) do advogado no interrogatório do acusado, à qual a doutrina e os tribunais resistiram até o advento da lei no ano de 2004;

f) até mesmo em determinados setores da pós-graduação stricto sensu (mestrado e doutorado) continua-se a fazer descrições de leis e casos (há dissertações e teses tratando de temáticas monográficas, mais apropriadas para cursos de especialização, para dizer o menos) - a maior parte desvinculada das linhas de pesquisa dos cursos, como, v. g., limitação de fim de semana na lei de execução penal, cheque pré-datado, saídas temporárias na lei de execução penal, inquérito policial, recurso de ofício, perda de bagagem em transporte aéreo, sistema postal, análise jurídica do lixo, o papel do oficial de justiça, o papel do árbitro, suspensão condicional da pena em ação penal privada, embargos infringentes, embargos declaratórios, união homossexual (em um Programa de PósGraduação que trata de meio-ambiente), embargos de execução, agravo de instrumento, exceção de pré-executividade, infanticídio, além de uma tese que, em pleno Estado Democrático de Direito, arrasa com o poder constituinte e outra que propõe a "inversão do ônus da prova penal" em crimes do colarinho branco, etc;

g) por outro lado, nem sequer conseguimos elaborar um novo modelo de provas de concursos públicos, continuando com a tradicional múltipla escolha - espaço (indispensável) para personagens fictícios como Caio, Tício e Mévio - e com questões dissertativas sobre casos jurídicos (no mais das vezes, sem qualquer sentido "prático") ou sobre conceitualizações jurídicas;

h) o modelo de decisão judicial continua o mesmo há mais de um século: a fundamentação restringese à citação da lei, da súmula ou do verbete, problemática que se agrava com a institucionalização da súmula vinculante. Daí a (correta) exigência Dworkin de uma "responsabilidade política" dos juízes. Os juízes têm a obrigação de justificar suas decisões, porque, com elas afetam, os direitos fundamentais e sociais, além da relevante circunstância de que, no Estado Democrático de Direito, 
a adequada justificação da decisão constitui-se em um direito fundamental. O sentido da obrigação de fundamentar as decisões previsto no art. 93, IX, da Constituição do Brasil implica, necessariamente, a justificação dessas decisões;

i) um dos indicadores da prevalência das posturas positivistas - e, portanto, da discricionariedade judicial que lhe é inerente - está no escandaloso número de embargos de declaração propostos diariamente no Brasil. Ora, uma decisão bem fundamentada/justificada (nos termos de uma resposta correta/adequada-à-Constituição, a partir da exigência da máxima justificação) não poderia demandar "esclarecimentos" acerca da holding ou do dictum da decisão. Os embargos de declaração - e acrescente-se, aqui, o absurdo representado pelos "embargos de pré-questionamento" (sic) demonstram a irracionalidade positivista do sistema jurídico;

j) registre-se o componente simbólico (lembremos Lacan e Castoriadis) desse problema: somos, provavelmente, o único país do mundo que mantém um "recurso" (embargos declaratórios) para compelir um juiz ou tribunal a fundamentar (explicitamente) aquilo que decidiu, muito embora a própria Constituição determine que todas as decisões sejam - obrigatoriamente - fundamentadas. Ora, parece óbvio que uma decisão carente de adequada (e necessária) fundamentação não enseja embargos de declaração. É, antes de tudo, nula, írrita, nenhuma.

h) não conseguimos ainda superar o problema exsurgente da relação "direito-moral", razão pela qual parcela considerável da comunidade jurídica continua a apostar na distinção estrutural entre regras e princípios, como se a diferença entre ambos fosse apenas semântico. Numa palavra, direito e moral possuem esse "ponto de estofo" (para usar uma expressão de Lacan) - que pode ser chamado de "co-ori-gi-nariedade", "complementariedade" ou "razão hermenêutica-estruturante-que-impedea-cisão-entre-o-direito-e-a-moral" - por-que o direi-to do Estado Democrático de Direito, sus-ten-ta-do nos prin-cí-pios que traduzem o mundo prático, origina-se de um lugar que não (mais) "sobrevive" como "território da convencionalidade jurídica" sem compromisso com a faticidade e a historicidade.

i) a moral não é (mais) uma instância paramétrico-corretiva, pela simples razão de que a fundamentação moral já está nesse "ponto de estofo" refe-ri-da "ao direito gerado democraticamente" e juridicamente institucionalizado. Expulsa pelo positivismo, ela retorna - agora como uma necessidade -, não mais como cor-re-ti-va/autô-no-ma, e, sim, traduzindo as insuficiências do direito que o positivismo pretendia que fossem dar "conta do mundo" a partir do "mundo de regras". Efetivamente, é por ela que o direito se abre ao déficit social representado pelo superado modelo liberal-individualista de direito. É nesse sentido que corretamente Vicente Barretto vai dizer que

o Estado Democrático de Direito, do ponto de vista jurídico-constitucional, expressa, assim, uma idéia moral de organização do poder político, antes de ser uma ordenação dos poderes do Estado e de definição de direitos e garantias individuais e coletivas. É, portanto, conseqüência, e não fonte, de uma determinada concepção de homem e da socieda-de, do homem considerado como ente moral, dotado de direitos anteriores à própria organização estatal. ${ }^{2}$

Por isso, para Barretto, o processo hermenêutico próprio do Estado Democrático de Direito supõe a consideração de princípios e condições sociais e políticas, não se confundindo com o jogo semântico ou com o entendimento da aplicação da lei como a simples subsunção da norma positiva aos fatos sociais. 
A institucionalização da moral no direito, a partir do direito gerado democraticamente (Constituições compromissório-sociais), mostra a especificidade do Estado Democrático de Direito, isto é, ambas as matrizes (teoria do discurso habermasiana e hermenêutica filosófica) somente se sustentam em sistemas jurídicos que promove(ra)m essa institucionalização. O direito incorporou um conteúdo moral, passando a ter um caráter de transformação da sociedade. Esse ideal de "vida boa" deve ser compreendido como dirigido e pertencente a toda a sociedade (esse é o sentido da moral), sendo a Constituição o modo para alcançá-lo. Com desideratos semelhantes, em Habermas o direito - a Constituição - garante abertura para que a justiça social venha a ser construída ao longo do tempo - daí a ênfase em uma democracia procedimental; na hermenêutica - na leitura feita no espaço destas reflexões - a aplicação da Constituição representa a concretização do conteúdo substancial e dirigente do texto; a hermenêutica não prescinde do procedimento, mas aposta na realização dos direitos substantivos, que tem caráter cogente, d'onde decorre uma maior valorização da jurisdição constitucional.

\section{AS POSSIBILIDADES DO NOVO: A NECESSIDADE DO RESGATE DAS PROMESSAS DA MODERNIDADE. HÁ UM DIREITO HUMANO- FUNDAMENTAL A UMA RESPOSTA ADEQUADA A CONSTITUIÇÃO?}

Na medida em que vivemos sob a égide de uma Constituição democrática, compromissória e quiçá, (ainda) dirigente, pareceria óbvio esperar que os juristas já tivessem construído um sentimento constitucional-concretizante nesses vinte anos que se completaram em 2008. Esse novo cenário exigiria um labor avassalador por parte dos juristas, pelo qual as leis infraconstitucionais deveriam ser simplesmente devassadas por uma implacável hermenêutica constitucional. Esse fenômeno, entretanto, ainda está longe de se realizar. Em todo esse período, se o legislador ficou aquém (vejase o problema dos velhos códigos) ou foi além do comando constitucional, pareceria evidente que a comunidade jurídica tomasse para si - mas sem protagonismos ad hoc - a tarefa de realizar o que se pode denominar de "filtragem hermenêuticoconstitucional", apontando as inconstitucionalidades (controle difuso e concentrado) e fazendo os necessários apelos ao legislador, além de construir uma teoria (doutrina) capaz de abarcar as demandas de um novo paradigma de direito e de Estado: o Democrático de Direito.

Não foi exatamente isso que ocorreu. Com efeito, se, durante o regime autoritário, buscávamos as brechas da lei e lutávamos a partir dessa frágil institucionalidade apostando em um antidedutivismo e em posturas que fizessem com que aquele direito fosse arrazado pela faticidade, agora, em plena produção democrática do direito, não parece ter muito sentido continuarmos a apostar em um protagonismo vencido pelos acontecimentos que culminaram na elaboração de um novo texto constitucional. Em outras palavras, antes não tínhamos constituição (e tampouco democracia) e éramos obrigados - os juristas críticos - a ser "realistas" ou "pragmatistas"; hoje, temos uma Constituição que deve ser o alfa e o ômega da conduta dos juristas e, por isso, a tarefa de qualquer teoria do direito preocupada com a democracia e os direitos fundamentais deve ser a de concretizar a Constituição. Isso significa dizer que não há mais espaços para voluntarismos e decisionismos baseados em discursos com pretensão corretiva. A interpretação do direito é incompatível com "graus zeros de sentido".

Lamentavelmente, o passar dos anos apenas mostrou que a dogmática jurídica - entendida em seu sentido mais tradicional - continuou dominando as práticas jurídicas, a ponto de colocar a doutrina como refém de uma jurisprudência construída ad hoc, em que o "caso jurídico" assume a função de álibi para construções pragmatistas, como se o direito (produzido democraticamente com berço constitucional) não tivesse "DNA". 
Enfim, ao invés de avançar em direção ao novo, o velho senso comum teórico - forjado em perspectivas positivistas-pragmatistas - transformou o direito em um somatório de decisões desconectadas, é dizer, em um verdadeiro "estado de natureza hermenêutico", no interior do qual cada juiz decide como mais lhe aprouver. Sob o álibi da "abertura interpretativa" proveniente da principiologia constitucional, parece não haver limites para a "criatividade", a ponto de, por vezes, soçobrar o próprio texto constitucional. E os exemplos não vários. Por todos - e, simbolicamente vale referir a proliferação de decisões que transformam o princípio da dignidade da pessoa humana em um "super-princípio", a falta de integridade e coerência na jurisprudência, o papel secundário assumido pela doutrina e a estandardização da produção literária, com o crescimento de uma cultura manualesca que apenas reproduz "conceitos lexicográficos".

A Constituição, que deveria ser o locus privilegiado para a obtenção de respostas concretizadoras, foi, ela mesma, transformada em um "texto aberto", por vezes, pan-principiologista. O dever fundamental de justificar as decisões foi derrotado por uma sistemática processual que apostou em uma cadeia recursal no qual os embargos declaratórios e embargos de pré-questionamento passaram a constituir a holding do sistema. Esse fenômeno alcança o seu auge, agora, com a edição de diversas leis que objetivam, efetivamente, "fechar o sistema", bastando, para tanto, examinar a série de leis que buscam essa "pós-modernidade quantitativa", como a Lei $\mathrm{n}^{\circ} .11 .277 / 06$, pela qual "quando a matéria controvertida for unicamente de direito e no juízo já houver sido proferida sentença de total improcedência em outros casos idênticos, poderá ser dispensada a citação e proferida sentença, reproduzindo-se o teor da anteriormente prolatada". Em resposta, o que ocorreu foi um silêncio eloqüente da comunidade jurídica fiel ao establishment instrumentalista do processo. E o que foi feito com os princípios do contraditório, da ampla defesa? E o que seria uma questão "unicamente de direito", como que a repristinar a dualidade "questão de fato-questão de direito", sustentada politicamente na institucionalização da Revolução Francesa e, filosoficamente, no paradigma da filosofia da consciência?

Já as leis que regulamentaram a repercussão geral ( $\mathrm{n}^{\circ}$. 11.417/06) e a nova forma de (in)admissão dos recursos junto ao STJ ( $\mathrm{n}^{\circ}$. 11.672/08) "avançaram" (sic) em relação à matéria. A partir de então, serão escolhidos um ou mais processos que representam a "essência" da controvérsia. Além do problema da limitação cognitiva (para usar uma expressão tão cara aos processualistas), várias questões causam perplexidade aos juristas preocupados com efetividades qualitativas, como "quem escolherá a 'amostragem'”, o caráter avocatório da sistemática (os demais processos ficam suspensos) e como delimitar a causa. Não esqueçamos que os julgamentos recursais devem tratar de causas e não de simples teses jurídicas. Com efeito, o princípio do due process of law, sob o seu viés substantivo, garante ao cidadão a procura do poder judiciário para que lhe proporcione uma proteção jurídica individual. Esse âmbito de proteção individual necessita a apreciação de todas as circunstâncias do caso concreto, aquilo alegado e provado em juízo, não se podendo tomar como base um esquema de representação fraca do fenômeno individual, muito menos do contexto históricofactual que tal processo envolve. A grande evolução do neo-constitucionalismo em garantir a recuperação do ideal de justiça ao dotar normativamente os princípios (e a inclusão da faticidade do mundo no direito) sofre, assim, um retrocesso pelo qual se procura estabelecer uma regra, geral e universalizante, que permita um julgamento massivo de todos os processos pressupostos como iguais. É a plenitude do princípio universalizante, ignorando a (im)própria dicotomia dos discursos de fundamentação e aplicação, transformando os segundos em primeiros.

Trata-se, portanto, de enfrentar os elementos fundantes do (velho) positivismo, mormente àquela que diz respeito à interpretação: a discricionariedade. Portanto, uma adequada crítica ao direito e à crise que o assola de há muito é não ter receio em apostar em algum tipo de racionalidade. Ou seja, levando em conta as promessas incumpridas da modernidade em terrae brasilis, a superação dos 
paradigmas metafísicos clássico e moderno - condição de possibilidade para a compreensão do fenômeno do constitucionalismo do Estado Democrático de Direito e da conseqüente superação do positivismo - não pode representar o abandono das possibilidades de se alcançar verdades conteudísticas. Sendo mais claro: a hermenêutica jamais permitiu qualquer forma de "decisionismo" ou "subjetivismo". Gadamer rejeita peremptoriamente qualquer acusação de relativismo à hermenêutica (jurídica). Falar de relativismo é admitir verdades absolutas, problemática, aliás, jamais demonstrada. A hermenêutica afasta o fantasma do relativismo, porque este nega a finitude e seqüestra a temporalidade. No fundo, trata-se de admitir que, à luz da hermenêutica (filosófica), é possível dizer que existem verdades hermenêuticas. A multiplicidade de respostas é característica não da hermenêutica, mas, sim, do positivismo.

As teorias consensuais da verdade mostram-se insuficientes para as demandas paradigmáticas no campo jurídico. Ao contrário da hermenêutica filosófica, não há ser-no-mundo nas teorias consensuais-procedurais, pelas quais só é possível atribuir um sentido a alguma coisa quando qualquer outra pessoa que pudesse dialogar comigo também o pudesse aplicar. Nelas, a condição de verdade das sentenças (enunciados) é o acordo potencial de todos os outros. Ou seja, nelas não há espaço para a substancialidade (conteudística). Portanto, não há ontologia (no sentido de que fala a hermenêutica filosófica). Isto demonstra que a linguagem - que na hermenêutica é condição de possibilidade -, nas teorias consensuais-procedurais, é manipulável pelos partícipes. Continua sendo, pois, uma terceira coisa que se interpõe entre um sujeito e um objeto, embora os esforços feitos por sofisticadas construções no plano das teorias discursivas-argumentativas.

Ou seja, é possível dizer, sim, que uma interpretação é correta, e a outra é incorreta (ou, se se quiser, adequada ou inadequada em relação à Constituição). Movemo-nos no mundo exatamente porque podemos fazer afirmações dessa ordem. E disso nem nos damos conta. Ou seja, na compreensão, os conceitos interpretativos não resultam temáticos enquanto tais, como bem lembra Gadamer; ao contrário, determinam-se pelo fato de que desaparecem atrás daquilo que eles fizeram falar/aparecer na e pela interpretação. Aquilo que as teorias da argumentação ou qualquer outra concepção teorético-filosófica (ainda) chamam de "raciocínio subsuntivo" ou "raciocínio dedutivo" nada mais é do que esse "paradoxo hermenêutico", que se dá exatamente porque a compreensão é um existencial (ou seja, por ele eu não me pergunto porque compreendi, pela simples razão de que já compreendi, o que faz com que minha pergunta sempre chegue tarde).

Ao contrário do que se diz, não interpretamos para, depois, compreender. Na verdade, compreendemos para interpretar, sendo a interpretação a explicitação do compreendido, para usar as palavras de Gadamer. Essa explicitação não prescinde de uma estruturação no plano argumentativo (é o que se pode denominar de o "como apofântico"). A explicitação da resposta de cada caso deverá estar sustentada em consistente justificação, contendo a reconstrução do direito, doutrinaria e jurisprudencialmente, confrontando tradições, enfim, colocando a lume a fundamentação jurídica que, ao fim e ao cabo, legitimará a decisão no plano do que se entende por responsabilidade política do intérprete no paradigma do Estado Democrático de Direito.

Mutatis, mutandis, trata-se de justificar a decisão (decisão no sentido de que todo ato aplicativo - e sempre aplicamos - é uma de-cisão). Para esse desiderato, compreendendo o problema a partir da antecipação de sentido (Vorhabe, Vorgriff, Vorsicht), no interior da virtuosidade do circulo hermenêutico, que vai do todo para a parte e da parte para o todo, sem que um e outro sejam "mundos" estanques/separados, fundem-se os horizontes do intérprete do texto (registre-se, texto é evento, texto é fato). Toda a interpretação começa com um texto, até porque, como diz Gadamer, se queres dizer algo sobre um texto, deixe primeiro que o texto te diga algo. O sentido exsurgirá de acordo com as possibilidades (horizonte de sentido) do intérprete em dizê-lo, d'onde pré-juízos inautênticos acarretarão graves prejuízos hermenêuticos. 
Se é verdade que as explicações decorrentes de nosso modo prático de ser-no-mundo (o-desde-jásempre-compreendido) resolvem-se no plano ôntico (na linguagem da filosofia da consciência, em um raciocínio causal-explicativo), também é verdadeiro afirmar que esse "modo ôntico" permanecerá e será aceito como tal se - e somente se - a sua objetivação não causar estranheza no plano daquilo que se pode entender como tradição autêntica. Nesse caso, devidamente conformados os horizontes de sentido, a interpretação “desaparece”. Em síntese, é quando ninguém se pergunta sobre o sentido atribuído a algo.

Mas, se essa fusão de horizontes se mostrar mal sucedida, ocorrerá a demanda pela superação das insuficiências do que onticamente objetivamos. Trata-se do acontecer da compreensão, pelo qual o intérprete necessita ir além da objetivação. Com efeito, estando o intérprete inserido em uma tradição autêntica do direito, em que os juristas introduzem o mundo prático seqüestrado pela regra (para utilizar apenas estes componentes que poderiam fazer parte da situação hermenêutica do intérprete), a resposta correta advirá dessa nova fusão de horizontes.

Por isso o acerto de Dworkin, ao exigir uma "responsabilidade política" dos juízes. Os juízes têm a obrigação de justificar suas decisões, porque com elas afetam os direitos fundamentais e sociais, além da relevante circunstância de que, no Estado Democrático de Direito, a adequada justificação da decisão constitui um direito fundamental. Uma decisão adequada à Constituição (resposta hermeneuticamente correta) será fruto de uma reconstrução histórica do direito, com respeito à coerência e a integridade (exame da integridade legislativa e respeito a integridade das decisões anteriores). Não haverá grau zero de sentido. A resposta adequada à Constituição deverá estar fundada em argumentos de princípio e não em argumentos de política (teleológicos), como bem ensina Dworkin. Do mesmo modo, a resposta correta deve buscar a preservação do grau de autonomia que o direito atingiu nesta quadra da história, evitando-se os "predadores" externos, como os discursos adjudicativos provenientes da moral, da política e da economia, assim como os "predadores" internos, como os subjetivismos, axiologismos e pragmatismos de toda a espécie.

\section{À GUISA DE CONSIDERAÇÕES FINAIS}

Parece indiscutível - diante do estado da arte da teoria do direito no Brasil - a necessidade de ultrapassar o "modo-positivista-de-fundamentar" as decisões (perceptível no cotidiano das práticas dos tribunais, do mais baixo ao mais alto); é necessário justificar - e isto ocorre no plano da aplicação - detalhadamente o que está sendo decidido. Portanto, jamais uma decisão pode ser do tipo "Defiro, com base na lei $x$ ou na súmula $y$ ".

A justificativa (a fundamentação da fundamentação, se assim se quiser dizer) é condição de possibilidade da legitimidade da decisão. Isso é assim porque o sentido da obrigação de fundamentar as decisões previsto no art. 93, inc. IX, da Constituição do Brasil implica, necessariamente, a justificação dessas decisões. Veja-se que um dos indicadores da prevalência das posturas positivistas - e, portanto, da discricionariedade (arbitrariedade) judicial que lhe é inerente - está no escandaloso número de embargos de declaração propostos diariamente no Brasil. Ora, uma decisão bem fundamentada/justificada (nos termos de uma resposta correta-adequada-à-Constituição, a partir da exigência da máxima justificação) não poderia demandar "esclarecimentos" acerca da holding ou do dictum da decisão. Os embargos de declaração - e acrescente-se, aqui, o absurdo representado pelos "embargos de pré-questionamento" (sic) - demonstram a irracionalidade positivista do sistema jurídico. Como é possível que se considere "normal" a não fundamentação de uma decisão, a ponto de se admitir, cotidianamente, milhares de "embargos"?

Nessa linha, a applicatio - porque interpretar é sempre um aplicar - evita a arbitrariedade na 
atribuição de sentido, porque é decorrente da antecipação (de sentido) que é própria da hermenêutica filosófica. Aquilo que é condição de possibilidade não pode vir a se transformar em um "simples resultado" manipulável pelo intérprete. Afinal, não podemos esquecer que mostrar a hermenêutica como produto de um raciocínio feito por etapas foi a forma pela qual a hermenêutica clássica encontrou para buscar o controle do "processo" de interpretação. Daí a importância conferida ao método, "supremo momento da subjetividade assujeitadora". Ora, a pré-compreensão antecipadora de sentido de algo ocorre à revelia de qualquer "regra epistemológica" ou método que fundamente esse sentido. Não há métodos e tampouco meta-métodos ou meta-critérios (ou um Grundmethode, para imitar Kelsen e "escapar" do problema - insolúvel - do fundamentum inconcussum). A compreensão de algo como algo (etwas als etwas) simplesmente ocorre (acontece), porque o ato de compreender é existencial, fenomenológico, e não epistemológico. Qualquer sentido atribuído arbitrariamente será produto de um processo decorrente de um vetor (standard) de racionalidade de segundo nível, meramente argumentativo/procedimental (Stein-Streck), isso porque filosofia não é lógica e, tampouco, um discurso ornamental.

Um caminho promissor para a construção das condições para o resgate das possibilidades concretizadoras da Constituição (e, portanto, para a efetividade dos direitos fundamentais-sociais) pode ser desenhado a partir da imbricação da hermenêutica filosófica com a teoria da "law as integrity" de Dworkin. Com efeito, ambas são anti-relativistas e anti-discricionárias, apostando, respectivamente, na tradição, coerência e na integridade para conter as "contingências" do direito, que seduzem os juízes a julgar pragmaticamente. Mais ainda, Gadamer e Dworkin não cindem "interpretação" de "aplicação". Para eles, não há grau zero na interpretação. As "contingências" são limitadas pela tradição/integridade/coerência.

Tanto em Gadamer como em Dworkin é possível distinguir boas e más decisões (pré-juízos autênticos/legítimos e inautênticos/ilegítimos) que, quaisquer que sejam seus pontos de vista sobre a justiça e o direito a um tratamento igualitário, os juízes também devem aceitar uma restrição independente e superior, que decorre da integridade, nas decisões que proferem. Na especificidade, Dworkin, ao combinar princípios jurídicos com objetivos políticos, coloca à disposição dos juristas/ intérpretes um manancial de possibilidades para a construção/elaboração de respostas coerentes com o direito positivo - o que confere uma blindagem contra discricionariedades (se assim se quiser, pode-se chamar a isso de "segurança jurídica") - e com a grande preocupação contemporânea do direito: a pretensão de legitimidade. E aqui, a toda evidência, parece desnecessária a advertência de que não se está a tratar de simples ou simplista transplantação de uma sofisticada tese do common law para o terreno do civil law. Há, inclusive, nítida vantagem em falar em princípios - e na aplicação destes - a partir da Constituição brasileira em relação ao direito norte-americano. Do mesmo modo, há uma vantagem na discussão da relação "direito-moral" desde o imenso e intenso catálogo principiológico abarcado pela Constituição do Brasil, questão bem caracterizada naquilo que vem sendo denominado de institucionalização da moral no direito, circunstância, aliás, que reforça a autonomia do direito, mormente se não for entendido a partir de uma postura jurisprudencialista (mesmo nesta, há uma grande preocupação para não permitir que a jurisdição substitua a legislação). Fundamentalmente - e nesse sentido não importa qual o sistema jurídico em discussão -, trata-se de superar as teses convencionalistas e pragmatistas a partir da obrigação de os juízes respeitarem a integridade do direito e a aplicá-lo coerentemente.

Numa palavra: a resposta correta (adequada) tem um grau de abrangência que evita decisões ad hoc. Entenda-se, aqui, a importância das decisões em sede de jurisdição constitucional, pelo seu papel de proporcionar a aplicação em casos similares. Haverá coerência se os mesmos princípios que foram aplicados nas decisões forem aplicados para os outros casos idênticos; mas, mais do que isso, estará assegurada a integridade do direito a partir da força normativa da Constituição. 
Tudo isso compreendido a partir daquilo que venho denominando de "uma fundamentação da fundamentação", traduzida por uma radical aplicação do art. 93, IX, da Constituição. Por isso é que uma decisão mal fundamentada não é sanável por embargos (sic); antes disso, há uma inconstitucionalidade $a b$ ovo, que a torna nula, írrita, nenhuma!

A partir do exposto, entendo que é possível afirmar que, do mesmo modo que há o dever fundamental de justificar/motivar as decisões, existe também o direito fundamental a obtenção de respostas corretas/adequadas a Constituição. Mais do que isso: a obtenção de respostas adequadas a Constituição implica o respeito à democracia. Trata-se de um direito (humano) fundamental do cidadão. Ou seja, o cidadão tem o direito a uma accountabillity hermenêutica. Há uma ligação umbilical entre esse dever fundamental e esse direito fundamental. A complementariedade entre ambos representa uma blindagem contra interpretações deslegitimadoras e despistadoras do conteúdo que sustenta o domínio normativo dos textos constitucionais. Trata-se de substituir qualquer pretensão solipsista pelas condições histórico-concretas, sempre lembrando, nesse contexto, a questão da tradição, da coerência e da integridade, para bem poder inserir a problemática na superação do esquema sujeito-objeto pela hermenêutica jurídico-filosófica.

Isso tudo demonstra que, nos dias de hoje, em tempos de consolidação do Estado Democrático de Direito e de neoconstitucionalismo, há uma exigência de ruptura com o modelo - diga-se, positivista - até então vigente, que negava ao Direito uma função crítica e transformadora de realidade, ou seja, seu caráter prospectivo. É por isso que, diante dessas constatações, recorro à crítica de Vicente de Paulo Barretto, que, com a ironia da pergunta: "o que (ainda) falta para fazer efetivo essa nova perspectiva do Direito?", bem denuncia a necessária mudança de paradigma no âmbito da ciência jurídica:

Para que se defina essa categoria moral e jurídica, que caracteriza o estado democrático de direito, é necessário considerar qual a função do Direito situada acima de simples regulador dos conflitos sociais. Essa função, que se torna cada vez mais explícita na prática democrática, é a função crítica. O Direito, hoje, como ontem, situa-se tendo em vista um fato e, a maioria das vezes, contra o próprio fato. Assim, contra a injustiça contida no fato social do autoritarismo, luta-se pela necessidade de uma ordem jurídica; contra os abusos do uso da liberdade, o Direito é chamado a determinar os limites a serem respeitados. O que é necessário, então, para que o Direito possa, efetivamente, atender à sua vocação crítica? ${ }^{3}$

\section{NOTAS}

1 STRECK, Lenio Luiz. Hermenêutica jurídica e $(m)$ crise. 8.ed. Porto Alegre: Livraria do Advogado, 2008; __ Verdade e consenso. Constituição, Hermenêutica e Teorias Discursivas. Da possibilidade à necessidade de respostas corretas no direito. 3. ed. Rio de Janeiro: Lumen Juris, 2009.

${ }^{2}$ Cf. BARRETTO, Vicente de Paulo. Da inter-pre-ta-ção à her-me-nêu-ti-ca cons-ti-tu-cio-nal. In: LACOMBE, Mar-garida (Org.). 1988-1998: uma déca-da de Constituição. Rio de Janeiro: Renovar, 1999, p. 391.

${ }^{3}$ BARRETTO, Vicente. Perspectivas epistemológicas do direito no século XXI. In: ROCHA, Leonel Severo; STRECK, Lenio Luiz (Orgs.). Constituição, Sistemas Sociais e Hermenêutica. Anuário do Programa de Pós-Graduação em Direito da UNISINOS - Mestra e Doutorado. Porto Alegre: Livraria do Advogado, 2005, p. 252. 